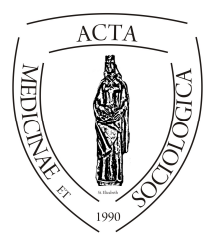

Acta Medicinae et

Sociologica (2019)

doi:

\title{
A támogató rendszerek szegregátumokban élő lakosságra gyakorolt hatása
}

\author{
Krizsai Anita \\ irodavezető, jogtanácsos, Nyíregyháza Megyei Jogú Város Polgármesteri Hivatal, Szociális és Köznevelési Osztály. \\ 4401 Nyíregyháza, Kossuth tér 1.
}

\section{INFO ABSTRACT}

\section{Krizsai Anita \\ krizsai.anita@nyiregyhaza.hu}

\section{Keywords}

social support system, apply and access in segregated areas

\begin{abstract}
The impact of the support system on people living in segregated areas. The Quality of Life Panel Research in Nyiregyháza (2008-2018) has been examining the changes in allowances. Similarly to the national data, there is a decrease in household allowance, the allowance for economically active people, and the number of people getting allowances. This study examines whether these tendencies are the same in two segregated areas, the Husar and Eastern settlements in Nyíregyháza, since here the residents are in a more disadvantageous position which stems from their education attainment, housing conditions, employment and related financial situation. Although the rate of those who live and get allowance is higher than that of the city dwellers, despite being entitled to allowances fewer people have applied for them. In this study we examine the underlying reasons by analysing our sample through social and economic characteristics, and along their changing attitude towards allowances.
\end{abstract}

\section{Kulcsszavak}

helyi szociális ellátórendszer, hozzáférés, célzottság, a szociális ellátórendszer változásai
Absztrakt. A Nyíregyháza Megyei Jogú Város és a Debreceni Egyetem Egészségügyi Kara együttműködésében megvalósuló "Nyíregyháza Város Életminősége" kutatássorozat lehetőséget nyújt a lakosság életminőségének vizsgálatára. A kutatás során az életminőség egyes elemeinek vizsgálatán túl elemezni tudtuk a szociális ellátások igénybevételének gyakorlatát, célzottságát, hatásosságát. Annak ellenére, hogy a helyi szociális ellátások és támogatások rendszere megőrizte stabilitását, a legújabb eredmények csökkenő igénybevételi rátákat mutattak. Ebben a tanulmányban megvizsgáljuk a fenti folyamatok főbb okait a mintába került lakosság szociális, gazdasági jellemzőinek elemzésével, valamint a segélyezéssel kapcsolatos attitűdök változása tükrében.

Ez a tanulmány a TOP-6.9.1-16-NY1-2017-00001 azonosító számú

"Közösen a kiútért" címü projekt támogatásával készült. 


\section{Bevezetés}

A Debreceni Egyetemnek az ország összes településére kiterjedő 2010 és 2013 között lezajlott adatgyüjtése szerint a teljes népességen belül 3,7 százalékról 8,8 százalékra nőtt a cigány népesség aránya az elmúlt 30 év alatt, ám a falvakban ennél magasabb, 11,5 százalék. A cigány népesség ma is kisebb településeken koncentrálódik: 37,8 százaléka falvakban, 32,8 százaléka városokban, 15,1 százaléka megyeszékhelyen vagy megyei jogú városban, és 14,3 százaléka Budapesten lakik. Ennek megfelelöen a falvakban élö teljesen népességen belül a legmagasabb az arányuk, 11,5 százalék, a legkisebb pedig a megyeszékhelyeken, ahol a teljes népesség 6,65 százalékát adják ők, de Budapesten is hasonló mértékü, kis híján 7 százalék az arányuk. Az adatok alapján megfigyelhető a cigányság növekvő urbanizáltsága, vagyis hogy egyre nagyobb részük él Budapesten és az 50 ezer föt meghaladó városokban, ahol számuk abszolút értékben is legalább kétszeresére gyarapodott. ${ }^{1}$ A Nyíregyházán élő romák arányát 8$10 \%$-ra becsülik, így számuk kb. 9-12000 főre tehető. A rendelkezésre álló adataink alapján kb. 15 \%-uk él szegregált körülmények között. A 2019-ben a Huszártelepen és a Keleti lakótelepen élők 40,2 \%-a vallotta magát cigánynak.

Nyíregyháza Integrált Városfejlesztési Stratégiája szerint Nyíregyháza területén három, rossz szociális és lakhatási körülményeket biztosító, hátrányos helyzetű családok által lakott szegregátum azonosítható: a Huszár lakótelep, a Keleti lakótelep és Polyákbokor. $^{2}$ Ezen részek területi nagysága, lakosságszáma eltérő, a lakosság demográfiai jellemzői, szociális mutatói azonban hasonlóak. Általánosságban a gyermek és fiatalkorúak magasabb aránya, iskolázatlanság, munkanélküliség, a rendszeres jövedelem hiánya, a nem megfelelő lakáskörülmények komplex problémahalmazként vannak jelen a telepeken.

A Huszártelep lakosainak száma 1679 fő (803 férfi és 876 nő), a 19-65 év közöttiek száma 1023 fö, a 0-18 év közöttiek száma 500 fö, a 65 felettiek száma mindösszesen 156 fö. A Keleti lakótelepen élők száma 526 fö, a 19-65 év közöttiek száma 260 fö, a 0-18 év alattiak száma 207 fö, a 65 év felettiek aránya 19 fó. A KSH 2015 évi adatai alapján a roma lakosság $20 \%$-a 20 év alatti, így a következő két évtizedben emelkedik a szülőképes korú nők létszáma, de kérdéses az újszülött nemzedékek számának alakulása, ugyanis a korfa alja nem szélesedik tovább, a 0-9 évesek száma kevesebb a tizenévesektől. ${ }^{3}$ Ez mindkét nyíregyházi telepre szintén igaz. A 18 év alattiak aránya a Keleti lakótelepen $40 \%$, a Huszártelepen $30 \%$. A városi lakosság $32,6 \%$-a gyermek vagy fiatalkorú. A városi adatokhoz képest eltérés az időskorú lakosság számában van, a városi idősek aránya 24,2 \%, a két telep esetén ez 3\% (Keleti lakótelep) és $9 \%$ (Huszártelep).

\footnotetext{
${ }^{1}$ Pénzes János-Tátrai Patrik-Pásztor István Zoltán: A roma népesség területi megoszlásának változása Magyarországon az elmúlt évtizedekben Területi Statisztika 2018.

${ }^{2}$ Az Anti-szegregációs tervben azon területeket/szegregátumokat kell feltüntetni, ahol az alacsony státuszú lakosok (aktív korú, 8 általános iskolai osztálynál nem magasabb iskolai végzettségü és rendszeres munkajövedelemmel nem rendelkező lakos) aránya minimum 50\%.

${ }^{3}$ KSH Statisztikai Tükör 2015.
} 
1990-ben a Huszártelepen élők közel egyharmada aktív kereső volt, 1993-ra gyakorlatilag mindenki munkanélkülivé vált. 2006-ban az itt élők közel 90 százaléka volt munkanélküli, ami továbbra is az alacsony iskolai végzettségükkel és a piacképes szakmák hiányával volt indokolható. Az 1990-es vizsgálat azt mutatta, hogy a háztartások egy főre jutó havi nettó jövedelme alapján a guszevi családok 89 százaléka abszolút és relatív értelemben is szegény volt. A város szociális irodájának adatai szerint 2005-re alig változott a helyzet, az itt élők megközelítőleg 90 százalékának jövedelme a medián jövedelem felét sem érte le. Ott, ahol az aktív korú családtagok munkanélküliek és jogosulatlanok a munkanélküli-ellátásra, a háztartás által megszerezhető jövedelem egyetlen biztos pontját a szociális juttatások, ezen belül főként a gyermekek után járó ellátások alkotják. ${ }^{4}$

Tanulmányunkban azt vizsgáljuk, hogy az elmúlt időszakban hogyan alakult a telepeken város lakosságához viszonyítva a segélyezettek köre, hogyan alakult helyzetük 2005-höz képest, a változásokhoz milyen okok vezettek.

\section{A telepen élők segélyezésében bekövetkezett változások}

A Nyíregyháza életminősége panelkutatás (2008-2018) során vizsgáltuk, hogy az elmúlt tíz évben milyen változások történtek a segélyezés terén. Az országos adatokhoz hasonlóan csökkent a lakásfenntartási támogatás és aktív korúak ellátásában részesülők száma 2012-hez képest, de jelentős volt a csökkenés a támogatottak számában 2017-ről 2018-as évre is. Megvizsgáltuk, hogy ez a tendencia figyelhető-e meg a Huszár-és Keleti lakótelepen élők esetében is. A telepeken élők döntő többsége jövedelmi viszonyokat tekintve a két alsó decilisbe tartozik, az átlagjövedelem rendkívül alacsony, így azt várnánk, hogy jelentős számban vesznek igénybe a járási hivatal és az önkormányzat által nyújtott támogatásokat. Az 1. táblázat a legnagyobb számban folyósított támogatásokat tartalmazza.

\begin{tabular}{|l|l|l|l|l|l|l|}
\hline & $\begin{array}{c}\text { Huszártelep } \\
\mathbf{2 0 1 3}\end{array}$ & $\begin{array}{c}\text { Huszártelep } \\
\mathbf{2 0 1 7}\end{array}$ & $\begin{array}{c}\text { Huszártelep } \\
\mathbf{2 0 1 8}\end{array}$ & $\begin{array}{c}\text { Keleti } \\
\text { lakótelep } \\
\mathbf{2 0 1 3}\end{array}$ & $\begin{array}{c}\text { Keleti } \\
\text { lakótelep } \\
\mathbf{2 0 1 7}\end{array}$ & $\begin{array}{c}\text { Keleti } \\
\text { lakótelep } \\
\mathbf{2 0 1 8}\end{array}$ \\
\hline $\begin{array}{l}\text { aktív korúak } \\
\text { ellátása }\end{array}$ & 219 & 176 & 128 & 92 & 70 & 66 \\
\hline $\begin{array}{l}\text { lakásfenntartási } \\
\text { támogatás }\end{array}$ & 131 & 133 & 103 & 44 & 39 & 31 \\
\hline $\begin{array}{l}\text { rendszeres } \\
\text { gyermekvédelmi } \\
\text { kedvezmény }\end{array}$ & 336 & 414 & 343 & 132 & 105 & 103 \\
\hline
\end{tabular}

Forrás: Járási Hivatal, Polgármesteri Hivatal adatai 2013, 2017, 2018

1. táblázat A Járási Hivatal és a Polgármesteri Hivatal által folyósított támogatások száma (fö)

4 Kerülő Judit: Az integráció és a szegregáció kérdése egy iskolabezárás kapcsán. http://ofi.hu/tudastar/kerulo-judit-integracio (2019.10.19.) 
A táblázatból látható, hogy a segélyezettek számában 2013-hoz képest itt is változás tapasztalható. Ha a lakásfenntartási támogatásban részesültek számát összevetjük a lakott lakások számával (Huszártelepen 244, Keleti lakótelepen 112), akkor a két telep között van egy kisebb különbség. 2018-ban a Huszártelep esetében a háztartások 42 \%-a kapott támogatást, mely a Keleti lakótelep esetén $27 \%$. Viszont mindkét telepre igaz, hogy 2018-ra egy év alatt $20 \%$-kal csökkent a támogatásban részesítettek száma. Ha összevetjük azokkal az adatokkal, hogy jövedelmük hány \%-át költik lakbérre, illetve rezsire (legalább jövedelmük 20-30 \%-át erre fordítják), akkor alacsonynak tekinthető a lakásfenntartási támogatásban részesítettek száma. Annak ellenére sem kér a háztartások egy jelentős része segítséget, hogy válaszaik szerint 37,6 \%-uk már legalább kétszer elmaradt a lakbér fizetésével, illetve 32,5 \%-uk a közüzemi díj fizetésével. Figyelembe véve, hogy a telepeken lévő bérlakások bérleti díja rendkívül alacsony (komfortos és félkomfortos szerint 136 és $130 \mathrm{Ft} / \mathrm{m} 2 /$ hó, további kedvezményként ennek 50 \%át fizetik) nemcsak a bérleti díj, de a rezsiköltség egy jelentős részét is fedezné a lakásfenntartási támogatás összege (2500-7200 Ft).

A rendszeres gyermekvédelmi kedvezmény ma már nagyobb arányban természeti juttatásként segíti a családokat. A kedvezmények (ingyenes étkezés, ingyen tankönyv) inkább az óvodás és iskolás korban nyújtanak nagyobb segítséget. A telepen élő 3-18 év közötti gyermekek 68\%-a részesül támogatásban, ezzel szemben a városi gyermekek mindössze $12 \%$-a. A városi tendenciákkal összehasonlítva, ahol felére csökkent a jogosultak száma az elmúlt tíz évben, ez a telepre nem jellemző. Korábban feltételeztük, hogy a változások egyik oka, hogy a családok jövedelmi helyzetében bekövetkezett pozitív változás és a kedvezménynél rendkívül alacsony (az elmúlt tíz évben csak minimálisan emelt) jövedelemhatár miatt a családok elesnek a támogatástól. Ezt alátámasztják a telepi adatok, a telepeken az átlagjövedelem nagysága lehetővé teszi továbbra is a támogatásra jogosultságot (jövedelemhatár 38.475 Ft és 41.325 Ft).

Megvizsgáltuk a rendkívüli települési támogatásban ${ }^{5}$ részesülők számát. 2018-ban a Huszártelepen élők 59,4 \%-a, a Keleti lakótelepen élők 31 \%-a kapott támogatást, ők azonban évente 3-4 alkalommal.

A városi kutatás és a statisztikai adatok alapján is Nyíregyházán kedvezően alakult a foglalkoztatás, mely részben a közfoglalkoztatás rendszerének is köszönhetö. A közfoglalkoztatottak száma 2017-ben 3335 fö, felülreprezentáltak a nők (58,8 \%) és a legfeljebb 8 általános vagy az alatti iskolai végzettséggel rendelkezők (61 \%).

\footnotetext{
${ }^{5}$ A szociális rászorultságtól függő egyes pénzbeli és természetben nyújtott szociális ellátásokról szóló 3/2015 (II. 20.) önkormányzati rendelet 14. § (1) bekezdése szerint az önkormányzat pénzbeli vagy természetbeni rendkívüli települési támogatást állapíthat meg, egy naptári éven belül ugyanazon háztartás valamely nagykorú tagja részére havonta egy alkalommal - a létfenntartást veszélyeztető rendkívüli élethelyzetbe került, valamint az időszakosan vagy tartósan létfenntartási gondokkal küzdő azon személyek részére.
} 
Mindkét csoportra jellemző, hogy nehezebben találnak munkalehetőséget a nyílt munkaerőpiacon.

\begin{tabular}{|l|l|l|l|}
\hline Megnevezés & Férfi & Nö & $\begin{array}{l}\text { Összesen } \\
\text { (fö) }\end{array}$ \\
\hline 8 általános alatt & 161 & 268 & 429 \\
\hline 8 általános & 634 & 968 & 1602 \\
\hline szakmunkás & 290 & 279 & 569 \\
\hline középfokú & 127 & 527 & 654 \\
\hline felsőfokú & 35 & 86 & 121 \\
\hline Összesen: & 1247 & 2128 & 3375 \\
\hline
\end{tabular}

Forrás: NYÍRVV Kft. Közfoglalkoztatási Csoport, 2018

2. táblázat A foglalkoztatásban résztvevők iskolai végzettség szerinti megoszlása

2018-ban a Huszártelepen élők közül a közfoglalkoztatásba bevontak száma 210 fő (131 nő), a Keleti lakótelep esetén 156 (103 nő) fö volt. A telepen élők esetében is igaz, hogy felülreprezentáltak a nők. A huszártelepi aktív korú lakosok 20 \%-a közfoglalkoztatott, $12 \%$-a aktív korúak ellátásában részesül. Ez a Keleti lakótelep esetén $60 \%$, és $25 \%$. A két telepen élő felnőtt lakosok 75,6\%-a legfeljebb általános iskolai végzettséggel rendelkezik, a közfoglalkoztatottak $61 \%$-a szintén ebbe a kategóriába tartozik. A két telepről bevontak esetén a legfeljebb általános iskolai végzettséggel rendelkezők aránya 89 és 97\%, vagyis a közfoglalkoztatásban való részvétel a telepeken élők számára szinte az egyetlen lehetőség, mégis a válaszadók egynegyede $(24,4 \%)$ nyilatkozott úgy, hogy munkát keres. (2. táblázat)

Egy 2018-ban végzett kutatás eredményei alapján, melyet 15 településen végeztek, a szakemberek véleménye szerint a közfoglalkoztatásból kimaradók sem alkotnak homogén csoportot. Vannak, akik legális jövedelemmel nem rendelkeznek, de az informális gazdaság keretein belül dolgoznak, ezért nem kívánnak részt venni a közfoglalkoztatásban. Viszont vannak olyanok is, akik annyira eltávolodtak a munkaerőpiactól, hogy még közfoglalkoztatásba sem vonhatók be. Ök azok, akik, az együttmüködésre és a munkavégzésre már nem képesek, általában nagyon komplex problémákkal küzdenek, aminek része a mélyszegénység, a tanult tehetetlenség, különböző mentális zavarok és függőségek, alacsony motiváció és együttmüködési képesség. ${ }^{6}$

Előnyként értékelik a közfoglalkoztatásban résztvevők, hogy a közfoglalkoztatási bér magasabb, mint az aktív korúak ellátása foglalkoztatást helyettesítő támogatásának havi 22.800-Ft összege, amelyre egy családon belül, jogszabályban meghatározottak szerint, egy személy jogosult, így életkörülményeik javításához, a család

${ }^{6}$ Belügyminisztérium megbízásából a Hétfa Kutatóintézet Kft. és alvállalkozó partnerei (Agrárgazdasági Kutató Intézet, MTA Közgazdaság-és Regionális Tudományi Kutatóközpont) által készített Tanulmány. Szerződés száma: BM/12095-64/2017. A közfoglalkoztatás hatása a helyi gazdaságra, helyi társadalomra A tanulmány szerkesztője, kutatásvezető:Koltai Luca A tanulmány szerzői: Koltai Luca, Bördős Katalin, Csoba Judit, Herczeg Bálint, Hamza Eszter, Megyesi Boldizsár, Németh Nándor, Rácz Katalin, Szabó Dorottya, Váradi Mónika, Varga Eszter, Virág Tünde 
megélhetéséhez átmeneti jelleggel, de biztos havi jövedelmet érhetnek el. Ugyanakkor a telepi vizsgálatban részvevők több mint fele "elégedetlen” illetve ,, egyáltalán nem elégedett" a fizetésével (kétszer annyian, mint a nyíregyházi lakosok). Szintén a közfoglalkoztatással állhat összefüggésben, hogy arra kérdésre, hogy ha összehasonlítja háztartásának jövedelmét az elmúlt három évvel, a válaszadók 42,9\%-a szerint jövedelmi helyzetük nem változott, 30,8 \%-uk szerint rosszabb lett. Ha megnézzük a közfoglalkoztatási bér alakulását 2016-ról (79.155 Ft) 2017-re 2375 Ft-tal emelkedett, 2018-ra nem változott, és továbbra sem éri el a városra jellemző átlagjövedelmet $(96.000 \mathrm{Ft}){ }^{7}$

\section{Támogató rendszerek}

A Nyíregyházi életminősége panelkutatás 2008-2018 (Nyíregyháza életminősége, 2008, 2010, 2012, 201; Fábián és mtsai, 2018) adatai szerint a nyíregyházi lakosok bizalma nem változott jelentősen az elmúlt tíz évben. A szegregátumokban élők lényegesen nagyobb arányban jelölték meg a városlakókhoz képest, hogy számíthatnak a mesterséges támogató rendszerek segítségére is problémáik megoldásában.

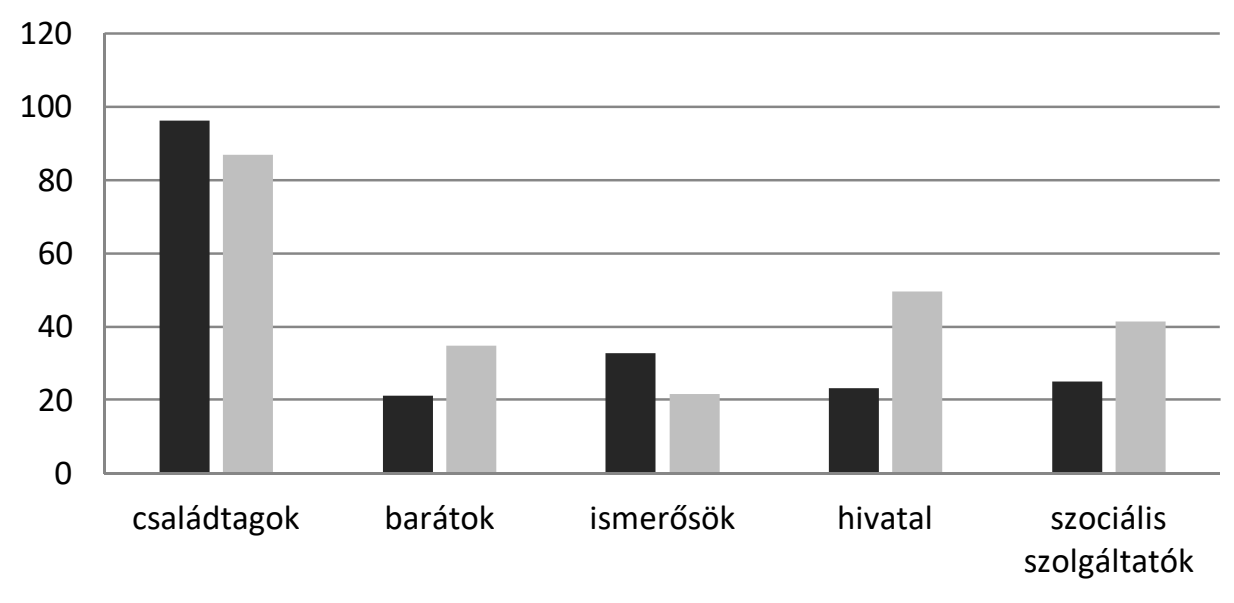

quáros Huszártelep és Keleti lakótelep

Forrás: Nyíregyháza életminősége panelkutatás 2018, Telepi kutatás 2019

1. ábra Szociálisproblémájának megoldásában kinek a segítségére számíthat? (\%)

Ha a kérdésre adott választ összevetjük azzal, hogy mennyire elégedettek az önkormányzattal, illetve a telepen lévő intézményékkel, akkor hasonló eredményeket kapunk. (1. ábra)

\footnotetext{
${ }^{7}$ Különbség van a közfoglalkoztatási bér és a garantált közfoglalkoztatási bér között, mely utóbbi a szakképzetteket illeti meg (összege 2016-ban bruttó 101.480 Ft, 2017 és 2018-ban $106.555 \mathrm{Ft})$.
} 


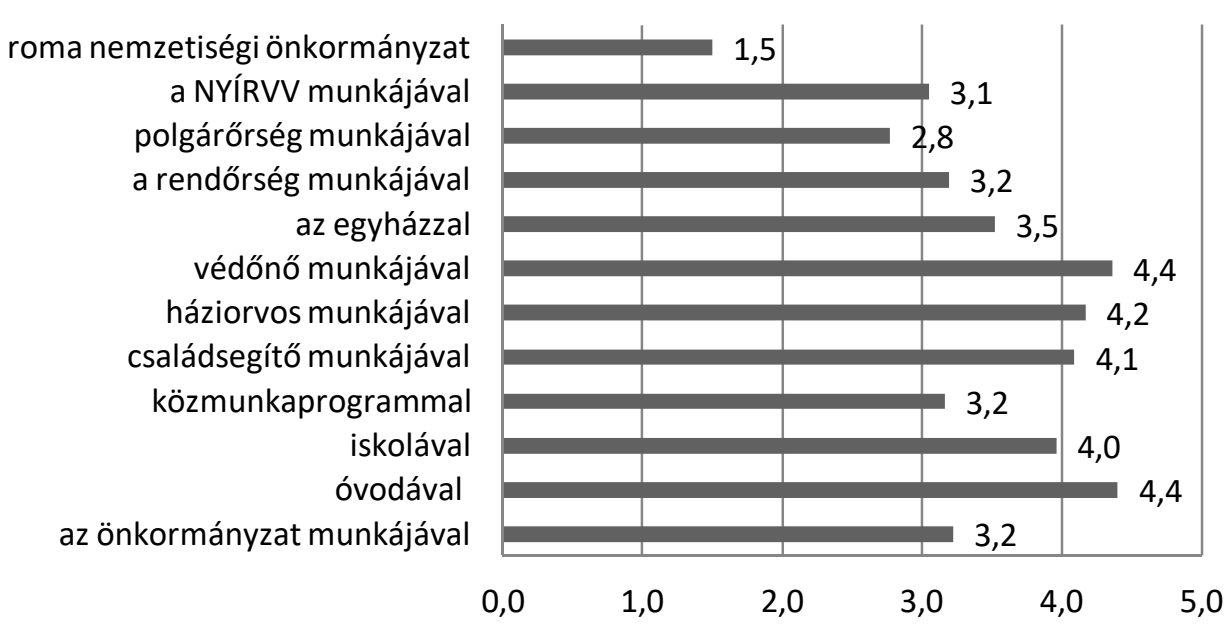

Forrás: Telepi kutatás 2019

2. ábra Mennyire elégedett a következö intézményekkel, szolgáltatásokkal? (1-5-ig, 1 nagyon elégedetlen, 5 maximálisan elégedett)

A legkedvezőbben a háziorvosok, illetve a védőnők munkáját ítélték meg, de általában véve elégedettek a többi intézménnyel is. Azonban kevésbé elégedettek a polgárőrség munkájával, valamint a megkérdezettek $86,5 \%$-a szerint a roma kisebbségi önkormányzat nem vagy egyáltalán nem segíti őket problémáik megoldásában annak ellenére, hogy mindkét szervezet mindkét telepen irodával rendelkezik, ami folyamatos jelenlétet tesz lehetővé. (2. ábra)

Ha azt vizsgáljuk meg, hogy a válaszadók szerint háztartásukban valaki jogosult lenne támogatásra a városi adatokhoz (20,3 \%) képest háromszor annyian válaszoltak a telepeken élők igennel (61,3\%). Míg a városban élőknek csak $36 \%$-a, addig a telepeken élők 59,4\%-a kért segítséget és 56,7\%-uk kapott is támogatást. A TÁRKI adati szerint ,a teljes magyar népességen belül tízből hárman éltek szegénységben vagy társadalmi kirekesztettségben 2009-ben (29,6 százalék), ami a következő években eleinte emelkedett, a 2013-as csúcson már 34,8 százalék volt, majd folyamatosan csökkent, és 2017-ben 25,6 százalékon állt. A szegénység azonban háromszoros arányban érte el a romákat a nem romákhoz képest: a romák háromnegyedével $(75,6$ százalék) szemben a nem romák negyede (24,7 százalék) élt szegénységben vagy kirekesztettségben, ami mindkét csoportban -hasonló ütemű csökkenés után -2014 óta 2017-ben a legalacsonyabb értéket jelenti."

A panel kutatás eredményei alapján azt feltételeztük, hogy azok nem kérnek támogatást, akiknek gyengébb az érdekérvényesítő képessége, az eljárás lefolytatásához szükséges képessége, nincs információja. A telepi kutatás fenti adatai alapján a tele-

8 Bernát Anikó: A magyarországi romák társadalmi integrációja a 2010-es években In:Társadalmi Riport 2018, 146. oldal 
pekre is igaz, hogy kevesebben veszik igénybe, mint amennyien jogosultak lennének, de többen is kérik a támogatást a város lakosságához képest.

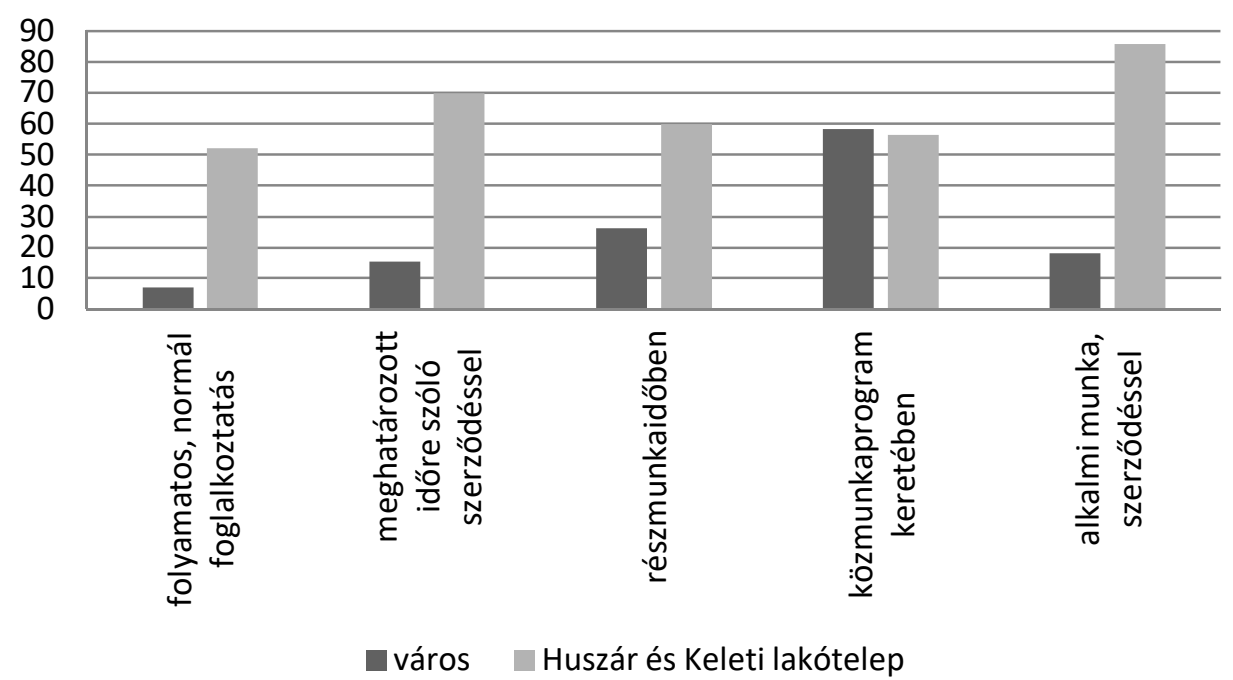

3. ábra A támogatást igénylők foglalkoztatási módja (\%)

A 3. ábrából jól látható, hogy a közmunkából származó jövedelem nem elégséges a megélhetéshez (lásd...oldal), de az is látható a folyamatos foglalkoztatás és alkalmi munka esetén is a telepeken nagyobb számban kérnek támogatást a városlakókhoz képest. Ha ezeket az a adatokat összevetjük iskolai végzettségükkel, a telepi átlagjövedelemmel, vélhetően teljes foglalkoztatásban is alacsony bért kapnak.

Ha a két telep segélyezési adatait hasonlítjuk össze, akkor látható, hogy a Huszártelepen élők nagyobb arányban részesülnek a különböző támogatási formákban. Vélhetően e mögött az állhat, hogy a Huszártelepen jóval több intézmény és szolgáltató van jelen, így vélhetően több információhoz és segítséghez jutnak az itt élők az elérhető támogatásokról, szolgáltatásokról. (4. ábra)

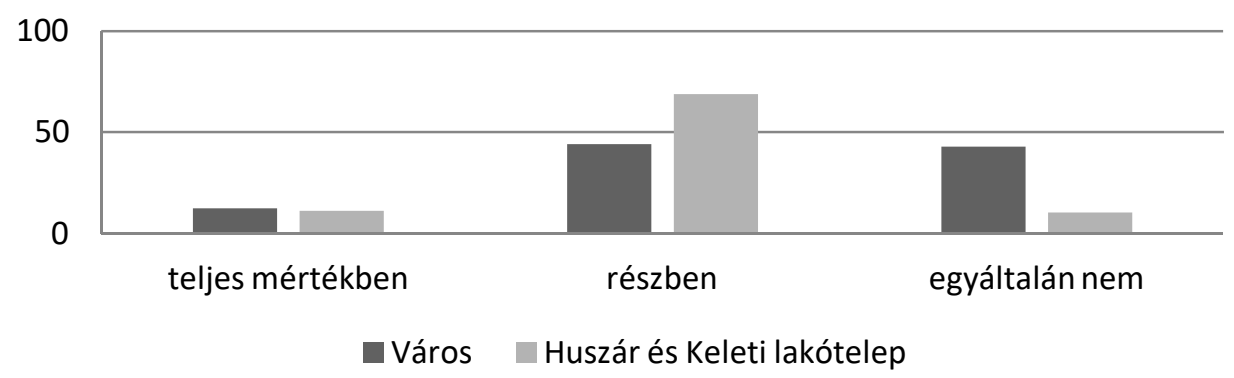

Forrás: Nyíregyháza életminősége panelkutatás 2018. Telepi kutatás 2019

4. ábra A megállapított segély megoldotta-e a problémáját? (\%) 
A kérdésre adott válaszok alapján a telepen élők számára nagyobb segítséget jelent a kapott segély. Ezzel áll összefüggésben az arra a kérdésre adott válasz, hogy milyen összegü segély, támogatás javítana a szociális helyzetén.

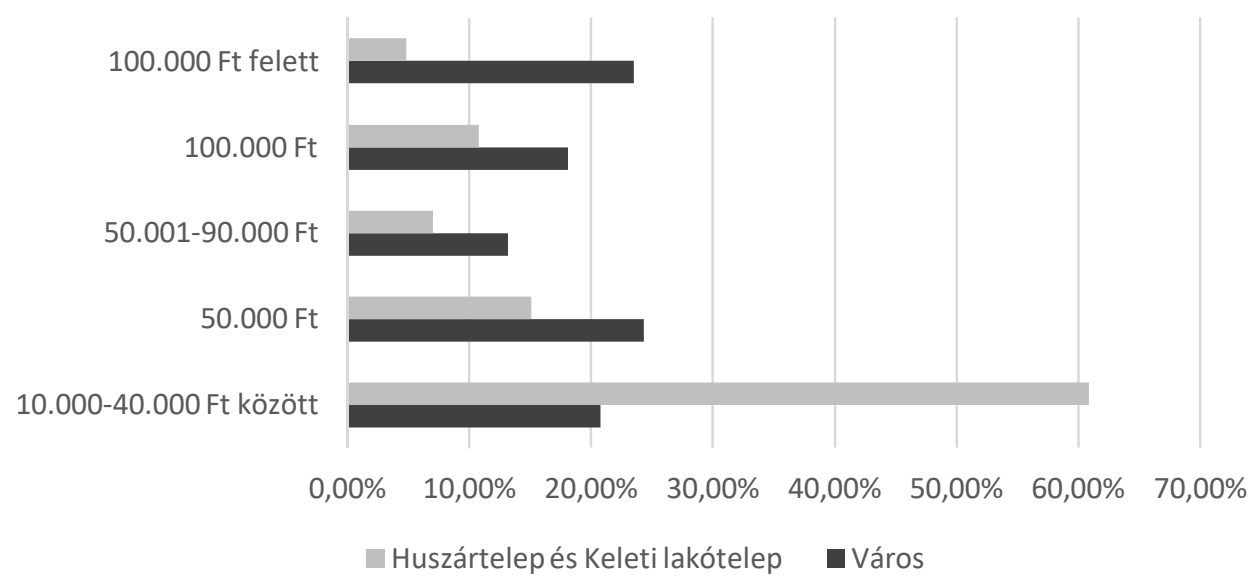

Forrás: Nyíregyháza életminősége panelkutatás 2018, Telepi kutatás 2019

5. ábra Megítélése szerint mekkora összegü segélyre, támogatásra lenne ahhoz szüksége, hogy szociális helyzetében pozitív változás kövezzen be \%

Az adatok alapján a telepen élő válaszadók 60 \%-a már 40.000 Ft és az alatti összeget is elégségesnek tart helyzete javulásához, míg a városban élők többsége nagyobb összeget jelölt meg. Ha ezt összevetjük azzal, hogy a telepen élők nettó átlagjövedelme $39.568 \mathrm{Ft}$, akkor elmondható, hogy elégedettek lennének, ha háztartásuk legalább a nyíregyházi átlagjövedelemmel rendelkezne. (5. ábra)

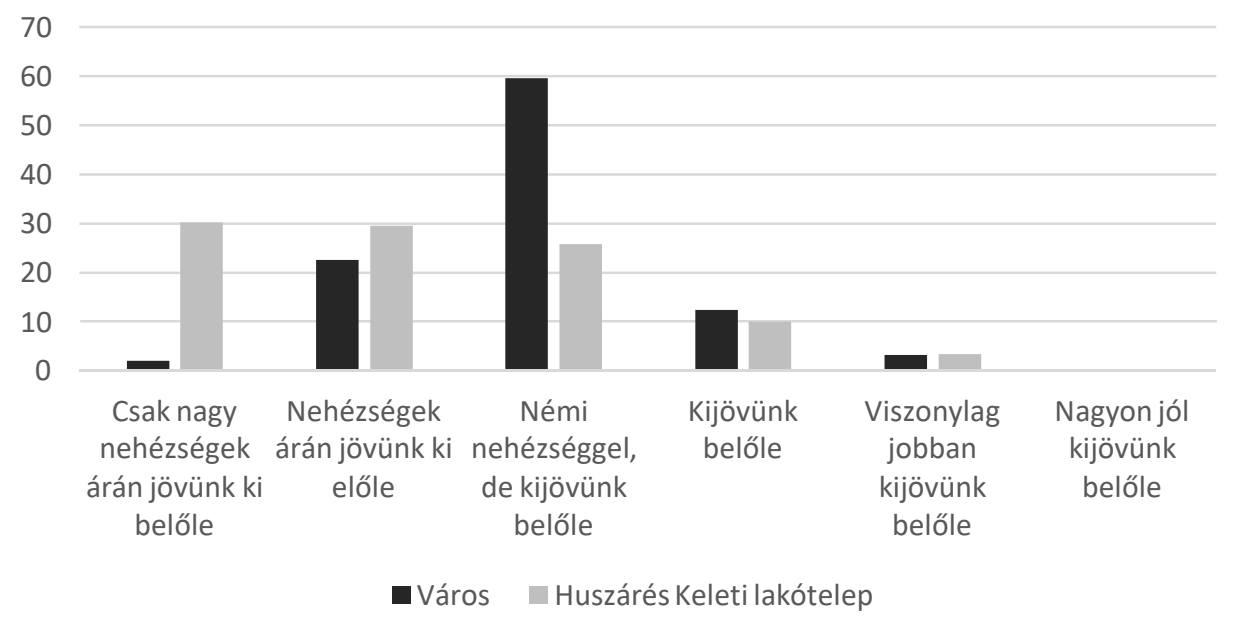

Forrás: Nyíregyháza életminősége panelkutatás 2018, Telepi kutatás 2019

6. ábra A válaszadók véleménye a háztartás havi jövedelme alapján megélhetésükről (\%) 
Ezzel összefüggésben azt is megvizsgáltuk, hogy jövedelmük mennyire elégséges megélhetésükhöz. A telepi lakosok közel $60 \%$-a nagy nehézségek árán, illetve nehézségek árán jön ki fizetéséből. (6. ábra)

A telepi kutatás során a fent elemzetteken túl számos egyéb kérdést is feltettünk a segélyezésre vonatkozóan, azonban ezekre értékelhető választ nem kaptunk.

\section{Összegzés}

Tanulmányunkban igyekeztünk bemutatni, hogyan alakul a két telepeken élők segélyezése, ebben milyen különbségek találhatók a két telepet egymáshoz és a városhoz viszonyítva. A városlakókhoz képest lényegesen magasabb a támogatásban részesülök száma, amely összefüggésbe hozható alacsony iskolai végzettségükkel, lakáskörülményeikkel, foglalkoztatottságukkal és ezekből adódó jövedelmi helyzetükkel. Azonban a telepek esetében is megfigyelhető, hogy kevesebben veszik igénybe a támogatásokat, mint amennyien jogosultak lennének. Ez a városlakókkal szemben nem vezethető vissza a jövedelmi helyzet kedvező változására, vagy arra, hogy kiadásaikhoz képest alacsony a támogatások összege. Esetükben inkább feltételezhető, az eljárási képesség, stb hiánya (pl.: számos kérdésünkre nem válaszoltak, nem tudták megmondani milyen segítségért fordultak a hivatalokhoz). Az ő esetükben még nagyobb probléma lehet, hogy a támogatásokat nem egy hivataltól kell már igényelni. A fentieket támasztja alá az is, hogy a két telep közül a Huszártelepen magasabb a segélyezettek száma, az itt lévő intézmények segítik, támogatják őket, így hozzájutnak a szükséges információkhoz is. A szolgáltatók jelenléte egyenlöre a Keleti lakótelep esetén kevésbé mondható el. A közfoglalkoztatás tekintetében szembetünő, hogy jóval nagyobb arányban vesznek részt a Keleti lakótelepről, amely nem indokolható képzettségbeli, illetve egyéb különbségekkel. A közfoglalkoztatást a Keleti lakótelep szomszédságában lévő NYÍRVV Nonprofit Kft. szervezi, így az itt élők számára könnyebben elérhető. Valóban jogos kutatótársam felvetése, vajon mennyire helyes, hogy a szolgáltatásokat a telepre visszük? Álláspontom szerint igen. Látható, hogy akkor jutnak közfoglalkoztatásba, akkor kapnak támogatásokat, szolgáltatásokat, ha azok könnyen elérhetők számukra. Azt gondolom, hogy a célcsoport felzárkóztatásához egyenlöre erre a közvetlen segítségre továbbra is szükség van.

Az önkormányzat arra törekszik, hogy a támogatások az arra rászorultakhoz jussanak el, jól célzottak legyenek. Mind a városi mind a telepi kutatás azt mutatja, hogy továbbra is szükséges a segélyezési rendszer fenntartása, hiszen a városban végbemenő kedvező folyamatok ellenére van egy olyan réteg, akiknek továbbra is hathatós segítséget jelentenek a különböző támogatások. A rászorultak egy része a két szegregátumban lakik, helyzetük bár 2005-höz képest valamelyest javult, azonban a városlakókhoz képest lemaradásuk továbbra is jelentős, az önkormányzatnak felelőssége, hogy felzárkóztatásukat segítse. 


\section{Irodalomjegyzék}

1. Hüse L., Takács P., Huszti É (szerk.) (2015): A Nyíregyházi járás életminősége 2015. Acta Medicinae et Sociologica Vol. 6. No. 18-19. 2015.

2. Belügyminisztérium megbízásából a Hétfa Kutatóintézet Kft. és alvállalkozó partnerei (Agrárgazdasági Kutató Intézet, MTA Közgazdaság-és Regionális Tudományi Kutatóközpont) által készített Tanulmány. Szerződés száma: BM/12095-64/2017. A közfoglalkoztatás hatása a helyi gazdaságra, helyi társadalomra A tanulmány szerkesztője, kutatásvezető:Koltai Luca A tanulmány szerzői: Koltai Luca, Bördős Katalin, Csoba Judit, Herczeg Bálint, Hamza Eszter, Megyesi Boldizsár, Németh Nándor, Rácz Katalin, Szabó Dorottya, Váradi Mónika, Varga Eszter, Virág Tünde

3. Bernát A. (2018): A magyarországi romák társadalmi integrációja a 2010-es években In: Kolosi T., Tóth I. Gy. (szerk.): Társadalmi Riport 2018. 144-165.

4. Fábián G., Patyán L., Huszti É. (szerk.) (2012): Életminőség Nyíregyházán 2008-2010. Acta Medicinae et Sociologica Vol. 3. No. 3.

5. Huszti É., Patyán L., Fábián G. (szerk.) (2014): Életminőség Nyíregyházán 2012. Acta Medicinae et Sociologica Vol. 5. No. 12-13.

6. Fábián G., Huszti É., Hüse L., Takács P. (2018): Az életminőség Nyíregyházán - A nagymintás társadalomkutatás első négy hulláma a megyeszékhelyen. Szabolcs-Szatmár-Beregi Szemle, 2018/3: 83-102.

7. Kerülő J. (2008): Az integráció és a szegregáció kérdése egy iskolabezárás kapcsán. Új Pedagógiai Szemle. http://ofi.hu/tudastar/kerulo-judit-integracio

8. KSH Statisztikai Tükör 2015

9. Pénzes J., Tátrai P., Pásztor I. Z. (2018): A roma népesség területi megoszlásának változása Magyarországon az elmúlt évtizedekben Területi Statisztika 2018/1: 144-165. doi: 10.15196/TS580101 